\title{
Diving behaviour of Mediterranean monk seal pups during lactation and post weaning
}

\author{
M. Gazo ${ }^{1,3, *}$, C. Lydersen ${ }^{2}$, A. Aguilar ${ }^{1}$ \\ ${ }^{1}$ Department of Animal Biology, Faculty of Biology, University of Barcelona, Avgda. Diagonal 645, 08028 Barcelona, Spain \\ ${ }^{2}$ Norwegian Polar Institute, 9296 Tromsø, Norway \\ ${ }^{3}$ Present address: Fundació CRAM, Camí Ral 239, 08330 Premià de Mar, Barcelona, Spain
}

\begin{abstract}
Time depth recorders (TDRs) were attached to 3 Mediterranean monk seal pups during a range of periods around weaning, providing a composite picture of activity from the first weeks of life until nutritional independence. The pups entered the water during their first week of life and their diving performance increase progressively with age. All pups spent most of their time at sea (55 to $74 \%$ ), and their swimming activity was greater at nighttime compared with daytime. Dive performance in relation to pup age was poorer compared with other phocid seal species. Dive types were classified using a combination of hierarchical and $k$-mean clustering. We found 3 dive types: $1 \mathrm{~V}$ shaped and $2 \mathrm{U}$-shaped. The most common type was $\mathrm{U}_{1}$-dives, mainly used by older pups during 44 to $48 \%$ of their total dive time. These dives were relatively deep and long (mean depth $=11.6 \pm$ $9.5 \mathrm{~m}$, mean duration $=149.1 \pm 80.6 \mathrm{~s})$. They had long bottom times $(100 \pm 67 \mathrm{~s})$, suggesting that pups were foraging. Pups appeared to start feeding at the end of lactation.
\end{abstract}

KEY WORDS: Mediterranean monk seal · Diving behaviour · Lactation · Weaning · Monachus monachus

Resale or republication not permitted without written consent of the publisher

\section{INTRODUCTION}

Populations of Mediterranean monk seals Monachus monachus have fallen sharply because of adverse interactions with humans such as deliberate killing, incidental catches, depletion of fish stocks and disturbance and habitat destruction (Brasseur et al. 1997). With fewer than 400 individuals worldwide (Aguilar 1999) this species is now listed as one of the most endangered mammals (IUCN 1996). Because populations were strongly reduced well before the turn of the twentieth century, the acquisition of knowledge on the behavioural and ecological traits of this seal has been hampered.

Unlike phocids from higher latitudes, the pupping seasons for monk seals are extremely protracted. Births in Mediterranean monk seals are recorded throughout the year, and a small peak occurs in October (Gazo et al. 1999). This non-seasonal breeding activity may be related to the stable weather condi- tions and relatively constant productivity of the area inhabited by these seals (Tilot 1993, Gazo et al. 1999). The nursing behaviour of the Mediterranean monk seal also differs from the phocid norm in that lactation is protracted, moult is not associated with weaning, females feed during the nursing period and pups remain unattended while females feed at sea (Gazo \& Aguilar 2005, Pastor \& Aguilar 2003).

Knowledge of diving behaviour contributes to an understanding of the foraging activity of a species and its habitat use. Extensive research on these areas has been carried out in phocids, but because of difficulties in the use and subsequent recovery of tracking equipment, only a few studies have focused on pups or recently weaned individuals. Thus, available data in this regard are limited to bearded seals Erignathus barbatus, ringed seals Phoca hispida, Weddell seals Leptonychotes weddelli, northern elephant seals Mirounga angustirostris and harbour seals Phoca vitulina (Lydersen \& Hammill 1993, Lydersen et al. 1994, Thor- 
son \& Le Boeuf 1994, Burns \& Castellini 1996, Bowen et al. 1999, Burns 1999, Hindell et al. 1999).

The diving behaviour of Mediterranean monk seal pups has received little attention to date. Here we used time-depth recorders (TDRs) to study the diving behaviour of these pups from nursing to nutritional independence.

\section{MATERIALS AND METHODS}

The study was carried out in the Cabo Blanco peninsula, Western Sahara $\left(21^{\circ} 02^{\prime} \mathrm{N}, 17^{\circ} 03^{\prime} \mathrm{W}\right)$ between July and November 1995. This area is inhabited by the only large aggregation of Mediterranean monk seals that exists today, with a total population estimated at 109 individuals (CV = 0.14; 95 \% CI: 86 to 145) (Forcada et al. 1999). Many individuals, including most lactating females and their pups, haul out onto the beaches and inside 2 caves, where they can be monitored easily (Gazo et al. 1999).

Seals were captured using a net mounted on a metal frame $(2.0 \times 1.3 \mathrm{~m})$. The frame was submerged horizontally in a natural channel (1 $\mathrm{m}$ deep) located near the entrance of the main breeding cave. When a pup swam on the surface just over the frame, a system of pulleys and weights was activated by the researchers to move the frame to the surface, thus entangling the pup in the net. No drug or anaesthetic was used to restrain the individuals. We attached Mk-5 TDRs (Wildlife Computers) to 4 moulted pups. These recorders were fixed with plastic zip ties to a plastic base that was glued to the seal's fur. At the end of the sampling period, we recovered the TDRs by entering the caves, approaching the sleeping individuals, and cutting the plastic zip. This operation did not require a second handling of the individuals tracked. The plastic base-plate then remained glued to the back of the seal until the next moult. We recovered 3 TDRs; another was lost because of the accidental breaking of the zip ties $6 \mathrm{~d}$ after attachment.

We made daily observations on the nursing behaviour of the tracked seals with a remote-control video camera which was installed on the roof of the breeding caves (Gazo et al. 1999). We then assessed behaviour at the end of the lactation period through observations conducted by scan sampling every 30 to $60 \mathrm{~min}$ and ad libitum sampling between scanning sessions (Altman 1974).

The TDRs were programmed to sample depth every $10 \mathrm{~s}$ with a resolution of $\pm 0.5 \mathrm{~m}$, and the data collected were analysed using Wildlife Computers software. We assigned the recordings of seal activity to 3 behavioural categories: (1) diving, when the TDR recorded depths greater than $2 \mathrm{~m}$ with dives longer than $20 \mathrm{~s}$;
(2) at surface, when the TDR was in the water, but depth readings were no greater than $2 \mathrm{~m}$ or the duration of the dive was less than $20 \mathrm{~s}$; and (3) hauled out, when the TDR indicated that the seal was out of the water for more than $1 \mathrm{~min}$. We also calculated the bottom time of each dive as the time interval between first and last depths spent at $85 \%$ of maximum depth of that dive or beyond. Times of the day registered by TDRs were set as local time (GMT - $1 \mathrm{~h}$ ).

In the dive analyses, we reduced potential aberrant behaviour caused by capture and handling by excluding dives that occurred before the first haul-out. The frequency distribution of dives indexed by time of day and maximum depth was determined using Surfer 5.01 (Golden Software).

We selected 8 variables for input into the diveclassification analyses following Krafft et al. (2000). These were (1) time at bottom divided by dive duration; (2) time at bottom divided by maximum depth; (3) maximum depth divided by dive duration; (4) average calculated ascent rate divided by average calculated descent rate; (5) average calculated descent rate divided by average calculated ascent rate; (6) maximum dive depth; (7) dive duration and (8) bottom time.

The variables did not show a normal distribution (Kolmogorov-Smirnov with the option Lilliefors, SYSTAT 7.0) and were therefore log-transformed and standardised to reduce discordance. Transformed data were subjected to principal component analyses (PCA) to reduce multi-colinearity. Only factors having eigenvalues $>1$ or accounting for at least $5 \%$ of the total variance were retained. The new uncorrelated variables were then used in cluster analyses. We selected a sample of 1000 dives (about 330 animal $^{-1}$ ) from the PCA results to run a complete-linkage hierarchical cluster analysis (SAS Institute). Following Krafft et al. (2000), we determined the number of clusters from the agglomeration coefficient. We chose the cluster level with the highest percentage change in this coefficient. Cluster centroids were established and used as seed points for further cluster analyses. After establishing the number of clusters, we performed a $k$-means cluster analysis with the whole data set (including the uncorrelated variables from the PCA). The results of this analysis produced summarized information about the dives in each cluster type.

\section{RESULTS}

\section{Age and lactation stage}

The ages of 2 of the pups (M11 and M16) were known precisely, as they had been monitored since birth (Table 1). The age of the third pup (M21) was 
estimated on the basis of morphological features and size (following Gazo et al. 1999), and its lactation stage was established through observations of suckling nearly 2 mo after the end of the tracking period. M16 was weaned during the tracking period, while M11 had already been weaned 2 to $3 \mathrm{wk}$ before attaching the TDR and was never observed engaging in nursing activity during the study. Tracking periods for each individual in real time and in relation to stage of lactation are shown in Table 1 and Fig. 1.

\section{Diving activity}

The TDRs recorded $1032 \mathrm{~h}$ of activity, which included 9827 dives (Table 2). Diving varied considerably between the 3 individuals (Figs. 2-4). The youngest pup, which was nursing throughout the tracking period (M21) spent $62.5 \%$ of its time in the water. However, only $7.5 \%$ of this time was spent diving, while the remaining $55 \%$ was spent at the surface. In addition, the little diving observed for this individual was shallow and of short duration (Table 2, Figs. $3 \& 4$ ). The pup that was weaned during the tracking period (M16) spent a total of $55 \%$ of its time in the water. However, the proportion of this time spent diving was much higher (20.5\%) than for M21 (Fig. 2). A comparison of pre- and post-weaning performance showed a marked change in diving activities performed by M16 (Figs. 1 \& 3). The dive frequency, their duration and depths all increased in the post-weaning period. The pup that was already weaned when tracking commenced (M11) spent $74 \%$ of its time in the water. Over $40 \%$ of this time was spent diving, and the depths and duration of dives were much higher than for the 2 other pups (Table 2, Figs. 3 \& 4).

These data show that there is an increase in dive performance with age, both in time spent diving and in dive parameters. Maximum dive depths increased from $13.0 \mathrm{~m}$ in M21 to $40.5 \mathrm{~m}$ in M11, and maximum duration from 6.5 to $18.3 \mathrm{~min}$ respectively. Concomitantly with increased dive performance, a decrease in duration of surface intervals was observed (Table 3).

In all 3 pups, dive frequency was lowest during the day (07:00-19:00 h) and highest during the night (19:00-07:00 h) (Mann-Whitney $U$-test, p < 0.009) (Fig. 4). This diurnal pattern was most marked in the 2 weaned seals, while the dives of the nursing pup occurred more from late afternoon until midnight, after which its diving activity reduced.

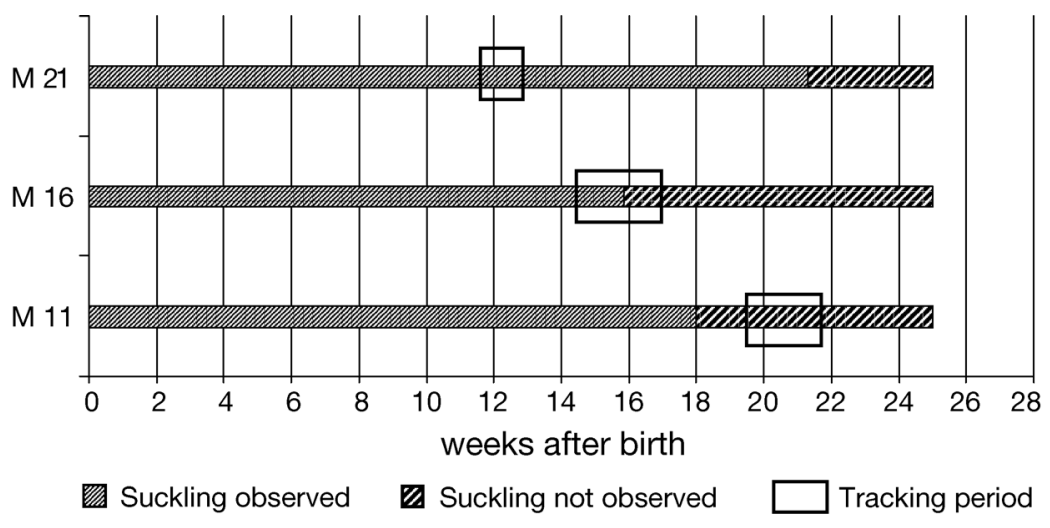

Fig. 1. Monachus monachus. Estimated periods of tracking in relation to birth and weaning for each pup

\section{Haul out}

All individuals hauled out daily. The percentage of time spent hauled out ranged from 26 to $45 \%$, and showed no clear trend with age or weaning stage (Fig. 2). However, after weaning, the number of haul-out bouts per day decreased while their duration increased (Table 3). At low tide the 3 pups tended to remain ashore in the caves. However, M11 and M16, the 2 oldest seals, only hauled out during daylight hours and spent the night diving, independently of the tide. 


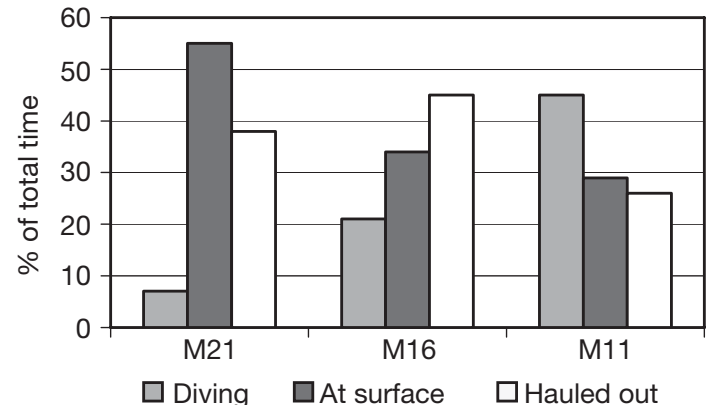

Fig. 2. Monachus monachus. Activity budget of the tracked individuals

\section{Dive categorization}

The dive classification analysis identified 3 distinct types: 4187 dives fell into cluster 1 (relatively deep Ushaped dives; $\mathrm{U}_{1}$-dive), 3207 into cluster 2 (V-shaped dives), and 2433 into cluster 3 (relatively shallow Ushaped dive; $\mathrm{U}_{2}$-dive) (Tables 4 \& 5). The 2 types of $U$ dive lasted longer than the $\mathrm{V}$-dives and had much
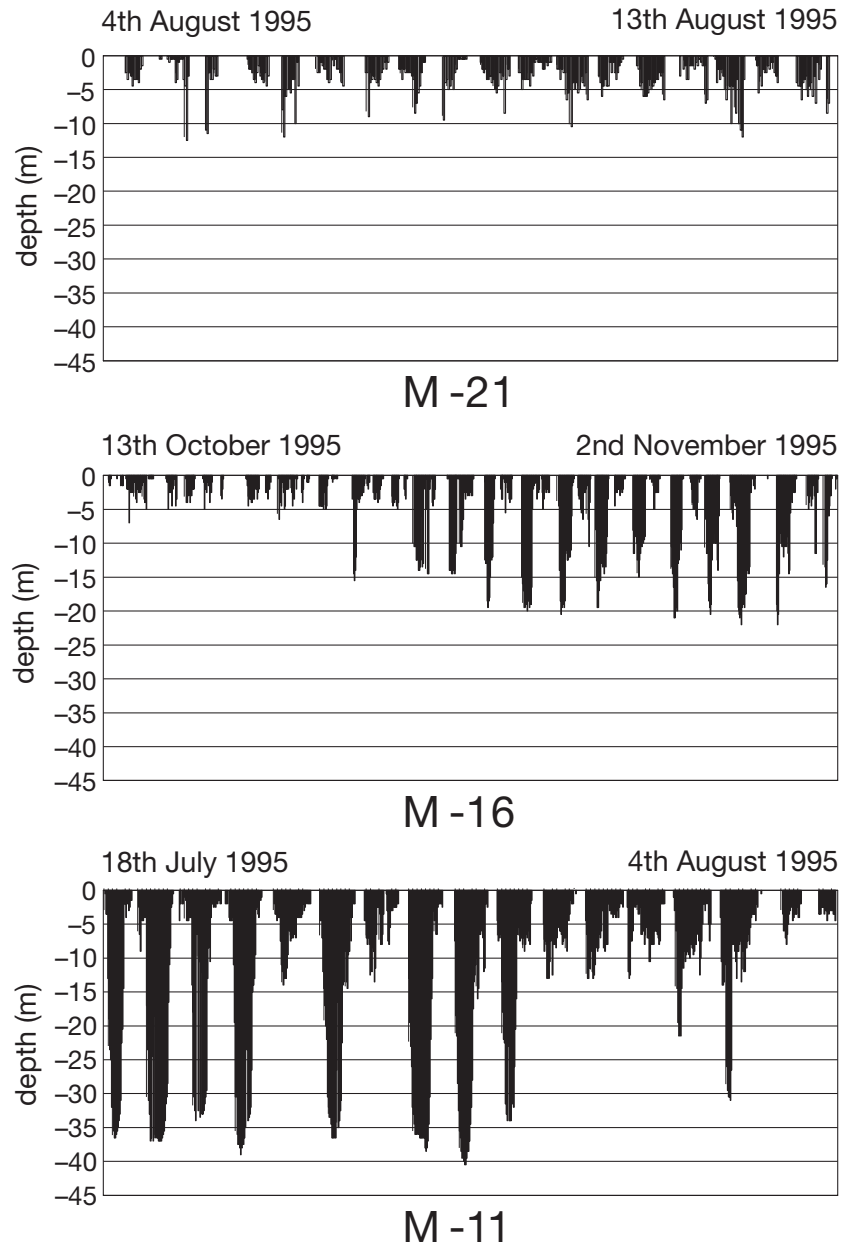

Fig. 3. Monachus monachus. Diving profiles of the tracked individuals longer bottom time. In addition to being shallower than $\mathrm{U}_{1}$-dives, $\mathrm{U}_{2}$-dives were also shorter in duration and bottom time, had slower ascent and descent rates and much longer post-dive surface intervals (Table 4).

Table 5 shows the proportion of dives that were assigned to the 3 dive types in each seal. Nearly half of the dives of the 2 oldest individuals (M11 and M16) were classified as $\mathrm{U}_{1}$-dives, while the youngest pup (M21) showed only a low percentage of this type of dive. The $\mathrm{U}_{2}$-dives accounted for a small proportion of the dives performed by the 3 seals, but the number of these dives appeared to increase slightly with age. Vshaped dives followed the opposite trend, and they were frequent only in the youngest individual.

\section{DISCUSSION}

Despite the small sample size, the TDR recordings of these 3 pups covered a range of periods around weaning and thus constitute a composite picture of the
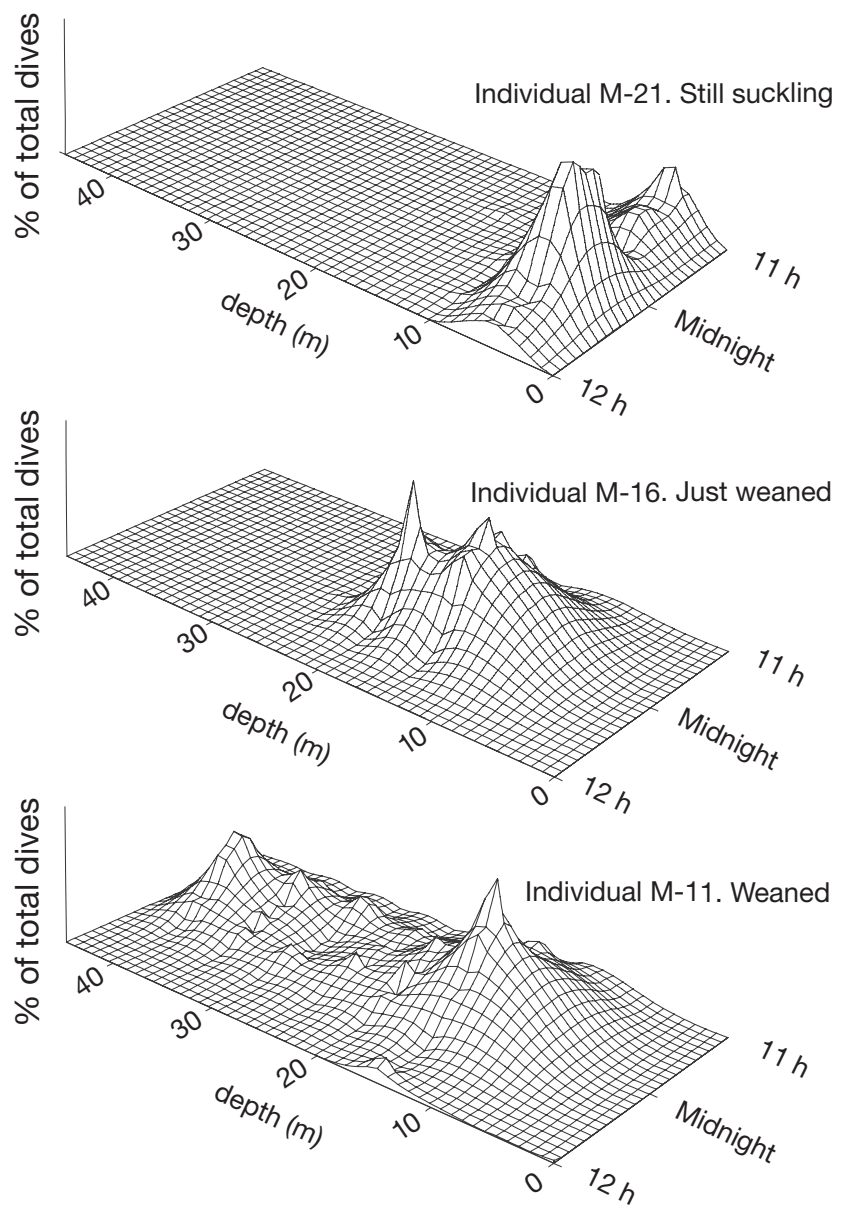

Fig. 4. Monachus monachus. Three-dimensional frequency distribution of depth of dive, time of day and number of dives in the 3 tracked individuals 
Table 3. Monachus monachus. Duration of surface and haul-out intervals $($ mean $\pm \mathrm{SD})$

\begin{tabular}{lccccc} 
Pup & $\begin{array}{c}\text { Mean duration } \\
\text { of surface } \\
\text { intervals (min) }\end{array}$ & $\begin{array}{c}\text { Max. duration } \\
\text { of surface } \\
\text { intervals (h) }\end{array}$ & $\begin{array}{c}\text { Duration of } \\
\text { haul-out } \\
\text { periods (h) }\end{array}$ & $\begin{array}{c}\text { Max. duration } \\
\text { of haul-out } \\
\text { periods (h) }\end{array}$ & $\begin{array}{c}\text { No. of } \\
\text { haul outs } \\
\mathrm{d}^{-1}\end{array}$ \\
\hline M21 & $5.55 \pm 19.03$ & 5.35 & $1.80 \pm 2.31$ & 9.18 & 4.99 \\
M16 & $2.67 \pm 12.42$ & 4.18 & $4.80 \pm 3.75$ & 15.04 & 2.24 \\
M11 & $1.30 \pm 3.82$ & 2.07 & $4.21 \pm 3.44$ & 14.02 & 1.40 \\
\hline
\end{tabular}

Table 4. Monachus monachus. Statistics (mean $\pm \mathrm{SD}$ ) of the 3 dive types obtained after classification of dives $(>2 \mathrm{~m})$ by a combination of hierarchical and a hard $k$-means cluster analysis

\begin{tabular}{|lccc|}
\hline Cluster & $\begin{array}{c}\text { Type } \mathrm{U}_{1} \\
\text { (deeper) }\end{array}$ & $\begin{array}{c}\text { Type } \mathrm{U}_{2} \\
\text { (shallower) }\end{array}$ & Type V \\
\hline Number of dives & 4187 & 2433 & 3207 \\
Maximum depth (m) & $11.6 \pm 9.5$ & $4.9 \pm 4.1$ & $3.6 \pm 3$ \\
Duration (s) & $149.1 \pm 80.6$ & $113.4 \pm 55.7$ & $36.1 \pm 30.5$ \\
Bottom time (s) & $100.3 \pm 67.3$ & $59.7 \pm 49.1$ & $1.4 \pm 3.5$ \\
Descent velocity $\left(\mathrm{m} \mathrm{s}^{-1}\right.$ ) & $0.6 \pm 0.3$ & $0.1 \pm 0.1$ & $0.3 \pm 0.2$ \\
Ascent velocity (m s ${ }^{-1}$ ) & $0.4 \pm 0.3$ & $0.4 \pm 0.3$ & $0.3 \pm 0.2$ \\
Post-dive surface interval (min) & $0.8 \pm 2.9$ & $2.6 \pm 13.7$ & $3.8 \pm 13.1$ \\
\hline
\end{tabular}

ters because adults drive them away from breeding beaches. However, low food availability in inshore areas also forces juvenile seals, which are less efficient than adults at capturing prey, to move to distant, more productive waters (Rauzon \& Kenyon 1982). Although in the Cabo Blanco colony some adult males feed offshore (Gazo 1998), others establish aquatic territories in inshore waters and drive out conspecifics entering their territory, including juveniles (Marchessaux 1989). Locally dominant males are often observed feeding inside their territory (GRUMM-University of Barcelona, unpubl. data). Thus, the offshore trips observed in the recently weaned seals of Cabo Blanco may be the result of competitive exclusion.

The results of this study show that, concurrent with reduced suckling toward the end of the nursing period (Pastor \& Aguilar 2003), pups increase their proportion of U-dives. U-dives are strongly associated with feeding in other seal species (Lesage et al. 1999) and it is likely that monk seal pups also start to ingest food other than Table 5. Monachus monachus. Contribution (\%) of the various dive types to the diving activity of each tracked individual

\begin{tabular}{|lccl|}
\hline & $\begin{array}{c}\text { Type } \mathrm{U}_{1} \\
\text { (deeper) }\end{array}$ & $\begin{array}{c}\text { Type } \mathrm{U}_{2} \\
\text { (shallower) }\end{array}$ & V-shaped \\
\hline M21 & 10 & 20.9 & 68 \\
M16 & 44.9 & 21.9 & 33.3 \\
M11 & 48.8 & 27.7 & 23.7 \\
\hline
\end{tabular}

diving behaviour of Mediterranean monk seal pups during their transition to nutritional independence.

The 3 pups spent most of their time (55 to $74 \%$ ) at sea and, similar to adults (Gazo 1998), their swimming activity was greatest at night. Their diving patterns varied markedly with age. The youngest pup spent most of its aquatic time swimming at the surface, and the few dives observed were of short duration, mainly V-shaped, and shallow. The pup in the process of weaning spent considerably less of its aquatic time at the surface; it dived deeper and longer, and deep U-dives were more frequent. The weaned pup showed a notable increase in diving activity and spent more than half of its time at sea engaged in active diving. The dives were deeper and longer than for the other pups, and almost half of the dives were deep $\mathrm{U}_{1}$-dives. Some of these could only have been conducted far away from the coast because Cabo Blanco shores are very shallow and the $40 \mathrm{~m}$ isobath (the deepest recorded dive) is located $30 \mathrm{~km}$ offshore. In the Hawaiian monk seal, juveniles feed in distant, deep wa- milk towards the end of lactation. This assumption is reinforced by direct observations of monk seals ingesting prey while still nursing (Pastor \& Aguilar 2003).

This age-related increase in diving skills is similar to that described for bearded, ringed and harbour seal pups (Lydersen \& Hammill 1993, Lydersen et al. 1994, Bowen et al. 1999, Jørgensen et al. 2001). Pups of these species swim and dive long before weaning, which is not as abrupt since the pups start to ingest food other than milk while still nursing (Lydersen \& Hammill 1993, Lydersen et al. 1994, Bowen et al. 1999, Jørgensen et al. 2001, Pastor \& Aguilar 2003). In addition, unlike most phocids, the mothers of these seals feed during the lactation period (Boness et al. 1994, Lydersen \& Kovacs 1999, Gazo \& Aguilar 2005, Pastor \& Aguilar 2003).

Although Mediterranean monk seal pups enter water during their first week of life, this does not necessarily indicate that they are precocial compared with phocid species in which pups do not enter the water until they are weaned. The ratio between newborn and maternal body masses is sometimes used as a crude measure for precociality. In Mediterranean monk seals this ratio is among the lowest in phocids (newborn pup mass $18.7 \pm 3.2$ [SD] kg, $\mathrm{N}=4$, GRUMM-University of Barcelona, unpubl. data; maternal masses 250 to $360 \mathrm{~kg}$, Marchessaux 1989) and about half that of the bearded, harbour and hooded seals (Bowen 1991), the most precocial phocids. Aquatic activity normally 
commences after a build-up of sufficient thermal insulation, which, in the case of phocid seals, is a subcutaneous blubber layer. The pups of most phocids born with lanugo do not enter water before moulting (Bowen 1991) or, as is the case for the pagophilic ringed and Weddell seals, until their blubber layer has built up under the lanugo (Lydersen \& Hammill 1993, Burns \& Castellini 1996). Bearded seal pups, which are born with lanugo that is already moulting (Kovacs et al. 1996), enter the sea on the very day they are born (Lydersen et al. 1994), but their blubber layer is already well developed (Kovacs et al. 1996). In contrast, Mediterranean monk seal pups are born with a lanugo that molts at $50 \mathrm{~d}$ (Gazo et al. 1999). Both this species and the congeneric Hawaiian monk seal spend a lot of time in water long before moulting (Boness 1990). No information is available about body composition of these 2 species at birth but, given their distribution in temperate to tropical latitudes, the thermal stress caused by entering water is probably much lower than in the above-mentioned pagophilic species, and thus makes such aquatic behaviour possible.

If pup age rather than lactation stage is considered, the diving skills of Mediterranean monk seals are not very impressive compared with those of other phocids. Lactation in Mediterranean monk seals is extremely protracted and lasts an average of $100 \mathrm{~d}$, with a recorded maximum of $150 \mathrm{~d}$ (Pastor \& Aguilar 2003). At the age of $100 \mathrm{~d}$, pups of all other phocid seals are fully aquatic and, for those that have been studied, diving skills are much more developed. For instance, monitoring of bearded seal pups younger than 2 mo showed that 6 out of 7 dived more than $450 \mathrm{~m}$ (Gjertz et al. 2000), and northern elephant seal pups undertook their first trip to sea at an age of 56 to $70 \mathrm{~d}$; almost immediately, they engaged in dives over $500 \mathrm{~m}$ which lasted longer than 20 min (Thorson \& LeBoeuf 1994).

There may be several explanations to account for the apparently limited diving behaviour of Mediterranean monk seal pups. In Cabo Blanco the continental platform is very wide and waters close to the coast are shallow. It can be argued that the profile of the sea bed limits the maximum depth reached by the pups. However, compared with the diving behaviour of pups of other phocids that also inhabit shallow waters, the performance of Mediterranean monk seals is much lower. Thus, in Sable Island (Nova Scotia), harbour seal pups routinely undertake $20 \mathrm{~m}$ deep dives from their second day of life (Bowen et al. 1999), while the pups of the Mediterranean monk seal only reach these depths at about 14 to $15 \mathrm{wk}$ of age.

Large body mass, the associated greater capacity to store oxygen and the generally less-mass-specific metabolic rates are other factors which may facilitate longer dives. Body mass in bearded and elephant seal pups is much greater than that in Mediterranean monk seals, and this might explain the interspecific differences observed. However, the development of diving in harbour seal pups does not appear to be restricted by oxygen stores or rates of oxygen consumption but rather by experience and learning (Jørgensen et al. 2001). If this principle were true for monk seal pups, they would display substantially more advanced diving because they are much older.

Another factor that may contribute to the interspecific differences observed is that Mediterranean monk seals, particularly those at Cabo Blanco, occupy productive waters with few seasonal changes in environmental conditions and food availability. These conditions may attenuate the stringent requirements that compel phocid pups in other areas to become skilled divers before a limited seasonal influx of prey. The availability of abundant food in shallow, coastal waters may also reduce the necessity for deep dives in distant ranges.

This study provides new information on diving development in pups of Mediterranean monk seals. Although highly aquatic, their performance as divers is not as developed as that of other phocid seals which occupy higher latitudes. Particular ecological traits of the Mediterranean monk seal and the mildness of its habitat may explain many of these differences.

Acknowledgements. The authors thank the members of the team who participated in the fieldwork at Cabo Blanco and, in particular, E. Grau, for his participation in the deploying and recovering of the TDRs. J. M. Burns, M. Craig and the personnel of Wildlife Computers assisted in various stages of the work, and special thanks go to B. Krafft for his help with the dive classifications. The European Commission LIFE project B4-3200/94/741/D2 funded this study.

\section{LITERATURE CITED}

Aguilar A (1999) Status of Mediterranean monk seal populations. RAC-SPA, United Nations Environment Program (UNEP), Aloès Editions, Tunisia

Altmann J (1974) Observational study of behaviour: sampling methods. Behaviour 49:227-267

Boness DJ (1990) Fostering behavior in Hawaiian monk seals: is there a reproductive cost? Behav Ecol Sociobiol 27: $113-122$

Boness DJ, Bowen WD, Oftedal OT (1994) Evidence of a maternal foraging cycle resembling that of otariid seals in a small phocid, the harbor seal. Behav Ecol Sociobiol 34: 95-104

Bowen WD (1991) Behavioural ecology of pinniped neonates. In: Renouf D (ed) Behaviour of pinnipeds. Chapman \& Hall, London, p 66-127

Bowen WD, Boness DJ, Iverson SJ (1999) Diving behaviour of lactating harbour seals and their pups during maternal foraging trips. Can J Zool 77:978-988

Brasseur SMJM, Reijnders PHJ, Verriopoulos G (1997) Mediterranean monk seal. In: Reijnders PJH, Verripopoulos G, Brasseur SMJM (eds) Status of pinnipeds relevant to 
the European Union. IBN Scientific Contributors, Vol 8. IBN-DLO, Wageningen, p 12-27

Burns JM (1999) The development of diving behavior in juvenile Weddell seals: pushing physiological limits in order to survive. Can J Zool 77:737-747

Burns JM, Castellini MA (1996) Physiological and behavioral determinants of the aerobic dive limit in Weddell seal (Leptonychotes weddellii) pups. J Comp Physiol B 166: 473-483

Forcada J, Hammond PS, Aguilar A (1999) Status of the Mediterranean monk seal Monachus monachus in the western Sahara and the implications of a mass mortality event. Mar Ecol Prog Ser 188:249-261

Gazo M (1998) Diving activity data of one of the most endangered divers: a Mediterranean monk seal adult male. How to obtain the information without disturbing the diver. In: Evans PGH, Parsons ECM, Clark SL (eds) European research on cetaceans. Proc 11th Ann Conf Eur Cetacean Soc, Stralsund, 10-12 Mar 1997, p 302

Gazo M, Aguilar A (2005) Mothering and diving behaviour of a Mediterranean monk seal lactating female. Mar Mamm Sci 21(2):340-345

Gazo M, Layna JF, Aparicio F, Cedenilla MA, González LM, Aguilar A (1999) Pupping season, perinatal sex ratio and natality rates of the Mediterranean monk seal from the Cabo Blanco colony. J Zool Lond 249:393-401

Gjertz I, Kovacs KM, Lydersen C, Wiig Ø (2000) Movements and diving of bearded seal (Erignathus barbatus) mothers and pups during lactation and post weaning. Polar Biol 23: 559-566

Hindell MA, McConell BJ, Fedak MA, Slip DJ, Burton HR, Reijnderss PJH, McMahon CR (1999) Environmental and physiological determinants of successful foraging by naïve southern elephant seal pups during their first trip to sea. Can J Zool 77:1807-1821

IUCN (1996) Red list of threatened animals. International Union for the Conservation of Nature and Natural Resources (IUCN), Gland

Editorial responsibility: Otto Kinne (Editor-in-Chief), Oldendorf/Luhe, Germany
Jørgensen C, Lydersen C, Brix O, Kovacs KM (2001) Diving development in nursing harbour seal pups. J Exp Biol 204: 3993-4004

Kovacs KM, Lydersen C, Gjertz I (1996) Birth-site characteristics and prenatal molting in bearded seals (Erignathus barbatus). J Mammal 77:1085-1091

Krafft BA, Lydersen C, Kovacs KM, Gjertz I, Haug T (2000) Diving behaviour of lactating bearded seals (Erignathus barbatus) in the Svalbard area. Can J Zool 78:1408-1418

Lesage V, Hammill MO, Kovacs KM (1999) Functional classification of harbor seal (Phoca vitulina) dives using depth profiles, swimming velocity and an index of foraging success. Can J Zool 77:74-87

Lydersen C, Hammill MO (1993) Diving in ringed seal (Phoca hispida) pups during the nursing period. Can J Zool 71: 991-996

Lydersen C, Kovacs KM (1999) Behaviour and energetics of ice-breeding, North Atlantic phocid seals during the lactation period. Mar Ecol Prog Ser 197:265-281

Lydersen C, Hammill MO, Kovacs KM (1994) Diving activity in nursing bearded seal (Erignathus barbatus) pups. Can J Zool 72:96-103

Marchessaux D (1989) Reserches sur la biologie, écologie et le status du phoque moine. PhD dissertation, Université de Marseille, GIS Posidonie, Marseille

Pastor T, Aguilar A (2003) Reproductive cycle of the female Mediterranean monk seal in the western Sahara. Mar Mamm Sci 19(2):70-82

Rauzon MJ, Kenyon KW (1982) Hawaiian monk seal inshore diving behaviour. Elepaio 42:107-108

Thorson PH, LeBoeuf BJ (1994) Developmental aspects of diving in northern elephant seal pups. In: LeBoeuf BJ, Laws RM (eds) Elephant seals: population ecology, behavior, and physiology. University of California Press, Berkeley, CA, p 271-289

Tilot V (1993) Description of the different large marine ecosystems of West Africa. IUCN Marine Program Project No. 9897. Large marine Ecosystem IUCN, Gland

Submitted: November 22, 2004; Accepted: July 21, 2005

Proofs received from author(s): January 4, 2006 